\title{
Gambaran Histopatologik Paru pada Hewan Coba Postmortem
}

\author{
${ }^{1}$ Sekar N. Ali \\ ${ }^{2}$ Sunny Wangko \\ ${ }^{2}$ Sonny J. R. Kalangi
}

\author{
${ }^{1}$ Program Studi Pendidikan Dokter Fakultas Kedokteran Universitas Sam Ratulangi Manado \\ ${ }^{2}$ Bagian Anatomi Histologi Fakultas Kedokteran Universitas Sam Ratulangi Manado \\ Email: Sali_11_304@yahoo.com
}

\begin{abstract}
Postmortem changes play an important role in estimation of the time of death. This study was aimed to obtain the histopathological changes of lungs at several time intervals postmortem. This was a descriptive observational study using a local pig as the animal model killed by stabbing in the heart. Lung samples were taken at 15 minutes, 30 minutes, 45 minutes, 60 minutes, 75 minutes, 90 minutes, 2 hours, 3 hours, 4 hours, 5 hours, 6 hours, 12 hours, and 24 hours postmortem. The results showed that the earliest histological change could be identified at 60 minutes postmortem in the form of alveolar dilatation. At 2 hours postmortem, congestion of smooth muscle layers of bronchioles was observed. The epithelial cells of the alveoli were undetected at 3 hours postmortem meanwhile the smooth muscle layers were undetected at 12 hours postmortem. At 24 hours postmortem, the bronchioles were still detected but the structure of their layers could not be identified. Conclusion: Histopathological changes were observed as alveolar dilatation at 60 minutes postmortem, followed by congestion of muscle layers, and undetected epithelial alveolar cells as well as smooth muscle layers. At 24 hours postmortem, bronchioles were still detected but the structure of their layers could not be identified.
\end{abstract}

Keywords: histological changes, lungs, postmorterm

\begin{abstract}
Abstrak: Perubahan postmortem berperan penting untuk memperkirakan waktu kematian. Penelitian ini bertujuan untuk mendapatkan perubahan histopatologik paru hewan coba postmortem pada beberapa interval waktu. Jenis penelitian ialah deskriptif-observasional menggunakan hewan coba satu ekor babi lokal yang dimatikan dengan tikaman pada jantung. Sampel paru diambil dalam waktu 15 menit, 30 menit, 45 menit, 60 menit, 75 menit, 90 menit, 2 jam, 3 jam, 4 jam, 5 jam, 6 jam, 12 jam dan 24 jam postmortem. Hasil penelitian mendapatkan pada 60 menit postmortem terjadi dilatasi alveoli. Pada 2 jam postmortem tampak kongesti lapisan otot polos. Pada 3 jam postmortem sel-sel epitel alveoli tidak tampak lagi dan pada 12 jam postmortem lapisan otot polos tidak terdeteksi. Pada 24 jam postmortem bronkiolus masih dapat dideteksi tetapi struktur lapisannya tidak teridentifikasi. Simpulan: Perubahan awal histopatologik paru babi postmotem ini dimulai pada 60 menit postmortem berupa dilatasi alveoli, diikuti kongesti lapisan otot polos, serta tidak terdeteksinya sel-sel epitel alveoli dan lapisan otot polos. Pada 24 jam postmortem bronkiolus masih terdeteksi tetapi struktur lapisannya tidak teridentifikasi lagi.
\end{abstract}

Kata kunci: perubahan histologik, paru, postmortem

Dalam bidang histologi, perubahan morfologik sel mati dapat dipergunakan sebagai alternatif memperkirakan lama waktu kematian dengan melihat perubahan- perubahan yang terjadi pada tubuh jenazah, diantaranya perubahan yang terjadi didalam sel. Kematian sel terjadi setelah kematian somatik. ${ }^{1}$ 
Memperkirakan saat kematian berperan penting bila dikaitkan dengan proses penyidikan. Perkiraan saat kematian dapat lebih mengarahkan penyidik secara terarah dan selektif dalam melakukan pemeriksaan terhadap tersangka pelaku tindak pidana. Dalam bidang forensik untuk perkiraan lama waktu kematian dapat digunakan pemeriksaan tanda-tanda kematian (lebam mayat, kaku mayat, penurunan suhu tubuh, pembusukan), serta pemeriksaan laboratorik (pemeriksaan serologik, toksikoogik dan histopatologik). ${ }^{2,3}$

Pemeriksaan histopatologik dilakukan untuk mengevaluasi perubahan morfologik sel mati yang dapat dilibatkan dalam perkiraan waktu kematian pada keadaan seperti mayat yang ditemukan termutilasi, digigit binatang buas, maupun mayat ditemukan terbakar sebagian yang masih sulit dievaluasi dengan menggunakan tanda-tanda kematian. ${ }^{4}$

Dalam penelitian ini dilakukan pemeriksaan histopatogik pada organ paru hewan coba postmortem untuk mengamati perubahan morfologik sel mati dalam memperkirakan waktu kematian. Hewan coba yang digunakan ialah babi karena hewan ini mempunyai karakteristik anatomi dan fisiologi yang mirip dengan manusia. Babi juga termasuk golongan omnivora, serta mempunyai flora saluran cerna dan histofisiologi kulit yang menyerupai manusia. ${ }^{5}$

\section{METODE PENELITIAN}

Jenis penelitian ini ialah deskriptifobservasional yang dilakukan di Bagian Anatomi-Histologi Fakultas Kedokteran Universitas Sam Ratulangi Manado dan Pusat Diagnostik Patologi Anatomi Manado. Hewan coba yang digunakan ialah satu ekor babi domestik dengan berat $20 \mathrm{~kg}$, secara fisik sehat, dan tidak ada luka.

\section{Prosedur Penelitian}

Hewan coba dimatikan dengan tikaman pada jantung. Setelah henti napas, waktu kematian dicatat. Pengambilan sampel paru dilakukan dengan beberapa interval waktu, yaitu: 15 menit, 30 menit, 45 menit, 60 menit, 75 menit, 90 menit, 105 menit, 2 jam, 3 jam, 4 jam, 5 jam, 6 jam, 12 jam dan 24 jam postmortem. Sampel yang diambil dimasukkan dalam botol yang sudah disiapkan lalu difiksasi dengan formalin $10 \%$. Penamaan pada setiap sampel dengan waktu pengambilan sampel dilampirkan untuk pembuatan preparat histologik di Pusat Diagnostik Patologi Anatomi Manado. Sediaan yang telah siap diidentifikasi dengan menggunakan mikroskop cahaya Olympus CX21 dan dibuat mikrofoto dengan menggunakan optilab. Perubahan histopatologik difokuskan pada bronkiolus dan alveoli.

\section{HASIL PENELITIAN}

Pada gambaran mikroskopik paru 15 menit sampai 45 menit postmortem terlihat bronkiolus dengan lapisan sel-sel otot polos dan alveoli dengan sel-sel epitel yang masih tampak normal (Gambar 1). Pada 60 menit postmortem tampak dilatasi alveoli dan sel-sel epitel tampak merenggang dengan jarak antar sel yang melebar (Gambar 2). Pada 2 jam postmortem bonkiolus masih tampak normal tetapi lapisan sel-sel otot polos mengalami kongesti (Gambar 3). Pada 3 jam postmortem sel-sel epitel alveoli tidak terlihat lagi (Gambar 4). Pada 12 jam postmortem sel-sel lapisan otot polos tidak terdeteksi (Gambar 5). Pda 24 jam postmortem bronkiolus masih dapat dideteksi tetapi struktur lapisannya tidak teridentifikasi lagi (Gambar 6).

Hasil penelitian perubahan histopatologik organ paru postmortem dapat dilihat pada Tabel 1 dan Gambar 1-6.

\section{BAHASAN}

Penelitian ini dilakukan untuk mendapatkan gambaran histopatologik paru postmortem pada hewan coba yaitu satu ekor babi domestik dengan berat $20 \mathrm{~kg}$. Pengambilan sampel dilakukan dalam beberapa interval waktu untuk mengamati perubahan yang terjadi sehingga dapat diaplikasikan dalam memperkirakan saat kematian. 
Tabel 1. Perubahan histopatologik organ paru yang dihubungkan dengan waktu postmortem

\begin{tabular}{cccccc}
\hline $\begin{array}{c}\text { Waktu } \\
\text { postmortem }\end{array}$ & Bronkiolus & $\begin{array}{c}\text { Lapisan sel } \\
\text { otot polos }\end{array}$ & $\begin{array}{c}\text { Sel epitel } \\
\text { alveoli }\end{array}$ & $\begin{array}{c}\text { Kongesti sel } \\
\text { otot polos }\end{array}$ & $\begin{array}{c}\text { Dilatasi } \\
\text { alveoli }\end{array}$ \\
\hline 15 menit & + & + & + & - & - \\
30 menit & + & + & + & - & - \\
45 menit & + & + & + & - & - \\
60 menit & + & + & + & - & + \\
75 menit & + & + & + & - & + \\
90 menit & + & + & + & - & + \\
105 menit & + & + & + & + & + \\
2 jam & + & - & - & + & + \\
3 jam & + & - & - & + & + \\
4 jam & + & - & - & + & + \\
5 jam & + & - & - & - & - \\
6 jam & + & - & - & - & - \\
12 jam & + & - & - & & + \\
24 jam & + & & & & - \\
\hline
\end{tabular}

Ket: + Teridentifikasi; - Tidak teridentifikasi

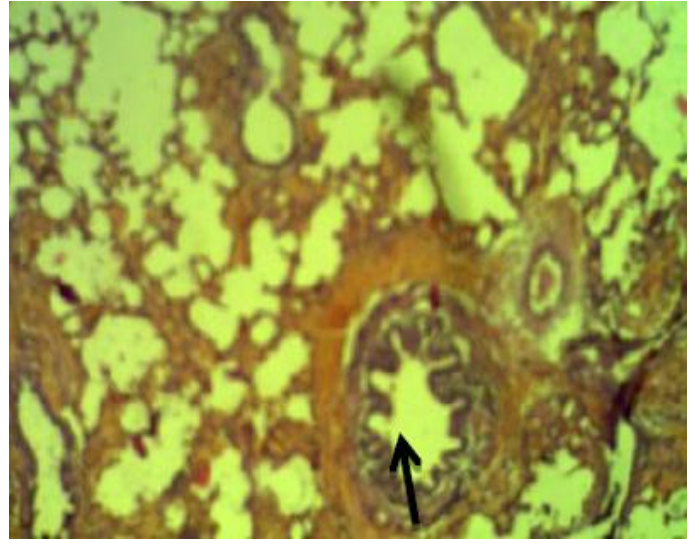

Gambar 1. Gambaran mikroskopik paru 15 menit postmortem bronkiolus dan alveoli nomal. Anak panah menunjukkan bronkiolus (Pembesaran 400x)

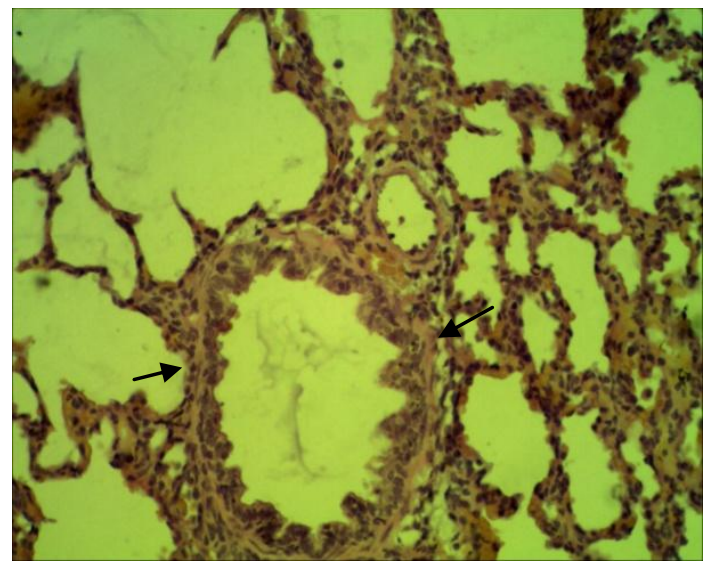

Gambar 3. Pada 2 jam postmortem tampak kongesti lapisan otot polos (Pembesaran 400x)

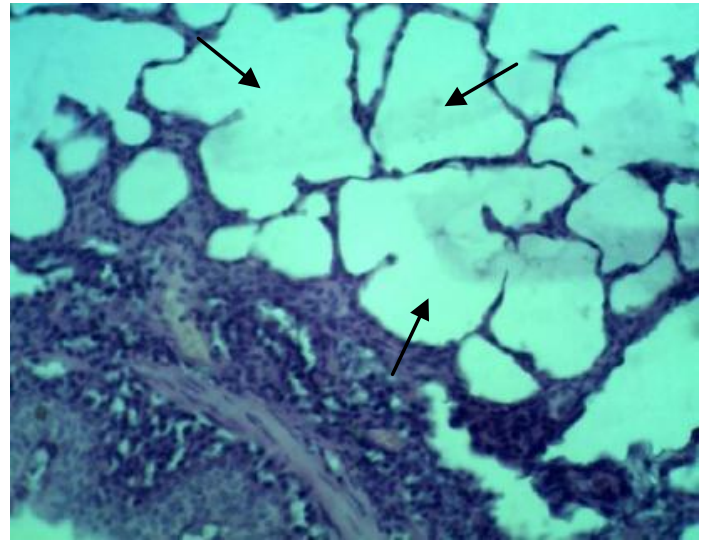

Gambar 2. Gambaran mikroskopik paru 60 menit postmortem, alveoli tampak berdilatasi (Pembesaran 400x)

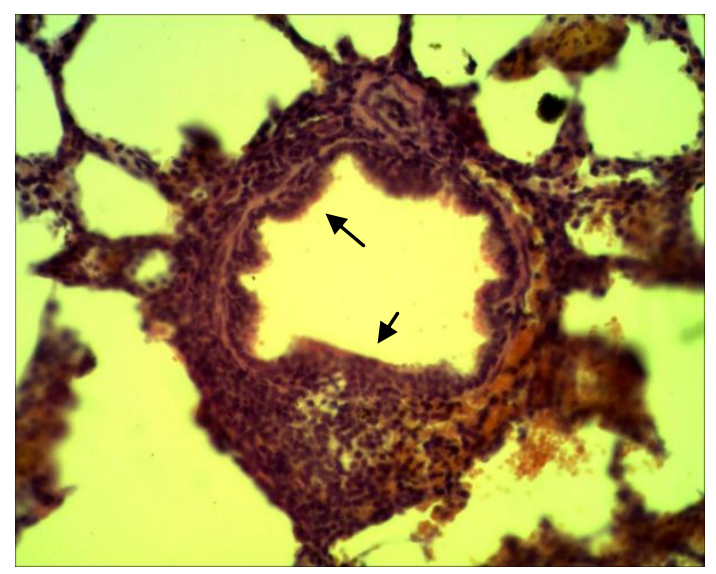

Gambar 4. Pada 3 jam postmortem sel-sel epitel alveoli tidak tampak lagi (Pembesaran 400x) 


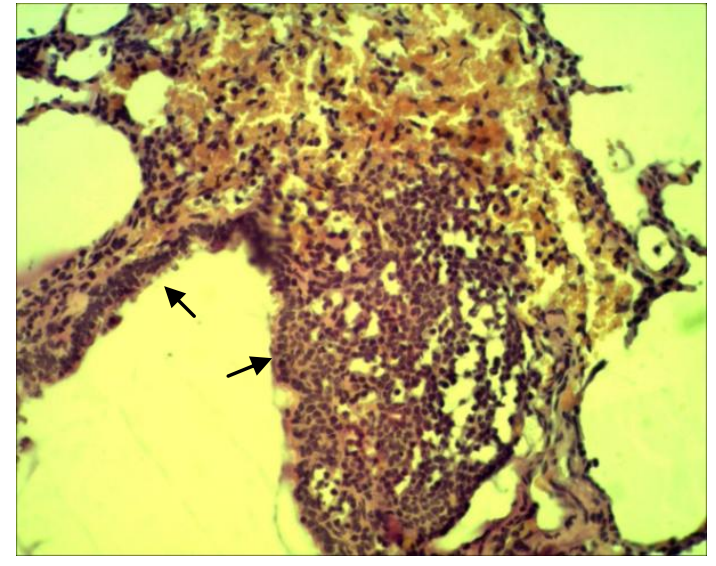

Gambar 5. Pada 12 jam postmortem sel-sel otot polos tidak dapat diidentifikasi (Pembesaran 400x)

Perubahan postmortem dapat memberikan banyak informasi baik mengenai saat kematian, penyebab, maupun mekanisme terjadinya kematian. Perkiraan saat kematian dapat dilakukan secara makroskopik dengan cara melihat tanda-tanda kematian, dan secara mikroskopik dengan melihat perubahan seluler akibat proses autolisis yang dimulai sejak kematian mahluk hidup. ${ }^{6,7}$

Pada makhluk hidup bila mengalami kematian maka akan terjadi pelepasan enzim-enzim dan mulai terjadi autolisis postmortem. Autolisis postmortem ialah kematian sel yang mirip dengan nekrosis yaitu kematian jaringan pada tubuh. Proses autolisis berkaitan dengan otopsi dari suatu fenomena untuk menjelaskan suatu kasus forensik. ${ }^{8}$

Pada penelitian ini gambaran histopatologik 15 menit sampai 45 menit postmortem menunjukkan bronkioli dan alveoli yang masih tampak normal. Hal ini tidak sejalan dengan penelitian Rahmadana et al. ${ }^{9}$ pada organ ginjal dengan hewan coba babi yang melaporkan perubahan histologik awal terjadi pada 30 menit postmortem yaitu adanya degenerasi hidropik sel-sel tubuli proksimal. Demikian pula dengan penelitian oleh Pualillin et al. ${ }^{10}$ yang menggunakan organ hati mendapatkan perubahan awal terjadi 30 menit postmortem berupa adanya kongesti parenkim hati disertai pelebaran sinusoid.

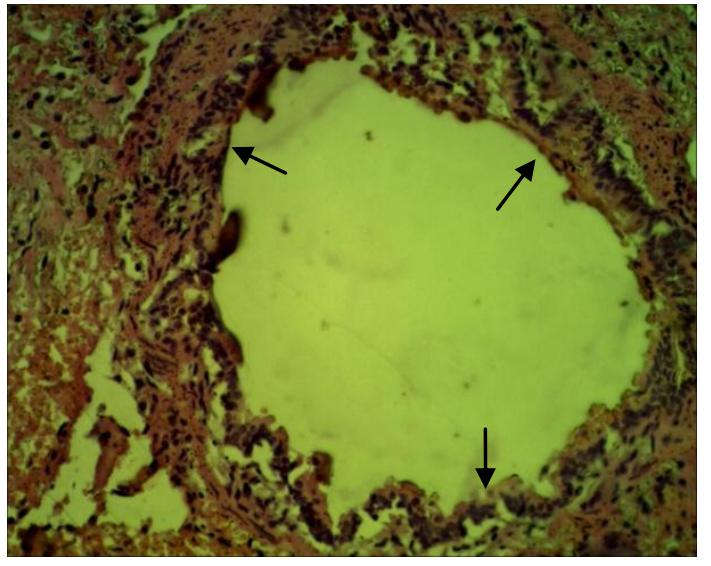

Gambar 6. Pada 24 jam postmortem bronkiolus masih dapat dideteksi tetapi struktur lapisannya tidak teridentifikasi (Pembesaran 400x)

Pada penelitian ini secara mikroskopik perubahan awal gambaran histologik paru terjadi 60 menit postmortem yang menunjukkan alveoli tampak berdilatasi dan selsel epitel merenggang. Hal ini sejalan dengan penelitian oleh Pontoh et al. ${ }^{11}$ yang melaporkan perubahan awal pada kandung kemih terjadi 60 menit postmortem berupa deskuamasi epitel dan kongesti.

Pada 2 jam paru postmortem penelitian ini menunjukkan bronkioli masih jelas walaupun sel-sel lapisan otot polos telah mengalam kongesti. Alveoli tampak berdilatasi dan sel-sel epitel rengang. Pada 3 jam postmortem sel-sel epitel alveoli tidak tampak lagi. Hal ini sejalan dengan penelitian oleh Piazza ${ }^{12}$ yang melaporkan bahwa organ paru mulai memburuk setelah 2 jam postmortem.

Penelitian menggunakan hewan coba babi juga digunakan pada berbagai organ. Penelitian oleh Lilingan et al. ${ }^{13}$ yang menggunakan organ gaster melaporkan perubahan histologik awal terjadi 2 jam postmortem pada kelenjar fundus. Goni et al. ${ }^{14}$ menyatakan perubahan awal 2 jam postmortem pada pankreas bagian eksokrin berupa adanya kongesti asini. Pada penelitian menggunakan usus besar oleh Lapian et al. ${ }^{15}$ didapatkan perubahan awal juga terjadi 2 jam postmortem berupa kongesti dan dilatasi kripta Lieberkhun. Theodore et al. ${ }^{16}$ melaporkan terjadi perubahan awal 2 jam postmortem pada 
struktur membran basalis dan kongesti kelenjar di usus halus. Savalinan et al. ${ }^{17}$ melaporkan perubahan awal mulai tampak pada 4 jam postmortem yang ditandai adanya kongesti, batas, dan inti sel epitel transisional pada ureter. Pada penelitian menggunakan organ limpa oleh Goni et al. ${ }^{18}$ didapatkan perubahan awal terjadi 5 jam postmortem ditandai dengan kongesti Malpighi.

Perubahan semakin tampak pada 12 jam sampai 24 jam postmortem dimana bronkioli masih dapat dideteksi, tetapi struktur sel-sel lapisan otot polos tidak teridentifikasi lagi. Berbeda dengan hasil penelitian Ubruangge et al. ${ }^{19}$ menggunakan otot jantung dan penelitian Nelwan et al. ${ }^{20}$ menggunakan otot skelet, pada 24 jam postmortem corak seran lintang masih dapat diidentifikasi pada kedua jenis otot tersebut.

Beberapa hasil penelitian di atas memaparkan perbedaan kecepatan autolisis. Hal ini sangat dipengaruhi oleh faktor lingkungan, yaitu suhu dan kelembaban. Semakin tinggi suhu semakin cepat proses autolisis. $^{21}$

Dengan membandingkan hasil-hasil penelitian di atas serta hasil penelitian ini dapat disimpulkan bahwa terdapat perbedaan waktu terjadinya perubahan histopatologik postmortem yang dapat dideteksi paling awal dan yang masih dapat bertahan sampai 24 jam postmortem.

\section{SIMPULAN}

Perubahan awal histologik paru babi postmortem ini dimulai pada 60 menit postmortem berupa dilatasi alveoli, diikuti kongesti lapisan otot polos, serta tidak terdeteksinya sel-sel epitel alveoli dan lapisan otot polos. Pada 24 jam postmortem bronkiolus masih terdeteksi tetapi struktur lapisannya tidak teridentifikasi lagi.

\section{SARAN}

Diharapkan hasil penelitian ini dapat diaplikasikan pada perkiraan saat kematian. Untuk itu diperlukan penelitian lanjut dengan menggunakan organ yang berbeda dan waktu pengambilan sampel yang lebih bervariasi agar dapat meningkatkan akurasi penentuan saat kematian.

\section{DAFTAR PUSTAKA}

1. Hubungan antara lama waktu kematian dengan kerusakan histopatologik otot jantung tikus Wistar. 2010. [cited 2014 Jan 22]. Available from: http://eprints.undip. ac.id/23135/1/Arie_Aldila.pdf

2. Howard C, Adelman M. Establishing the time of death. In: Forensic Medicine. New York: Infobase Publishing, 2007; p. 20-6.

3. Perbedaan kecepatan lisis sel ginjal tikus wistar pada media air tawar dan tanah. 2010. [cited 2015 Oct 22]. Available from: http://eprints.undip.ac.id/23650/1/prain dra.pdf

4. Hubungan lama kematian dengan kerusakan histopatologis otot gastrocnemius tikus wistar. 2010. [cited 2015 Oct 22]. Available from: http://eprints.undip. ac.id/23386/1/Hanindya.pdf

5. Swindle MM, Makin A, Herron AJ, Clubb FJ, Frazier KS. Swine as models in biomedical research and toxicology testing. 2012. Available from: http:// vet.sagepub.com/content/49/2/344.full. pdf + html

6. Morgan C, Nokes LD, Williams JH, Knight BH. Estimation of the postmortem by multiple-site temperature measurements and the use of a new algorithm. Forensic Sci Int. 1998;39(1): 89-95.

7. Fitria R. Tanda intravital yang ditemukan pada kasus tenggelam di Depertemen Kedokteran Forensik Fakultas Kedokteran Universitas Sumatrera Utara RSUP H. Adam malik/RSUD Pirigadi Medan pada bulan Januari 2007-2009. 2010. [cited 2015 Oct 12]. Available from: repository.usu.ac.id/ bitstrem/123456789/21606/4/chaper\%2 OII.pdf

8. Perbandingan antara durasi waktu pembekuan terhadap terjadinya pembusukan jaringan paru-paru pada kelinci. 2014. [cited 2015 Oct 22]. Available from: http://eprints.undip.ac.id/44885/AzisSf. pdf

9. Rahmadana B, Wangko S, Kalangi SJR. Gambaran histologik ginjal pada hewan coba postmortem. eBm. 2014;2(2):4138.

10. Pualillin NK, Wangko S, Kalangi SJR. 
Gambaran histologik hepar pada hewan coba postmortem. JBM. 2014;6(2):98104.

11. Pontoh LM, Kalangi SJR, Kaseke MM. Gambaran makroskopik dan mikroskopik kandung kemih pada hewan coba postmortem. eBm. 2017;5(1).

12. Piazza O, Romano R, Cotena S, Santaniello W, Robertis ED. Maximun tolerable warm ischaemia time in transplantasi from non-heartbeating-donors 2013. [cited 2013 Sept 9]. Available from: https://www. academia.edu/2517011/Maximum_tole rable_warm_ischaemia_time_in_transp lantation_from_non-heart-beatingdonors

13. Lilingan M, Kalangi SJR, Wangko S. Gambaran histologik gaster pada hewan coba selama 24 jam postmortem. eBm. 2016;4(1).

14. Goni LR, Wongkar D, Ticoalu SHR. Gambaran makroskopik dan microskopik pankreas pada hewan coba postmortem. eBm. 2017;5(1).

15. Lapian C, Wangko S, Wongkar D. Perubahan histologik pada usus besar hewan coba postmortem. eBm. 2016;4(2).

16. Theodore VJ, Wangko S, Kalangi SJR. Gambaran histologik usus halus pada hewan coba selama 24 jam postmortem. eBm. 2017;5(1).

17. Savalina DNS, Ticoalu SHR, Wangko S. Gambaran makroskopik dan mikroskopik ureter pada hewan coba postmortem. eBm. 2016;4(2).

18. Goni LR, Wongkar D, Wangko $S$. Gambaran makroskopik dan mikroskopik limpa pada hewan coba postmortem. eBm. 2017;5(1).

19. Ubruangge $T$, Wangko $S$, Kalangi SJR. Gambaran histologik otot jantung pada hewan coba postmortem. eBm. 2016;4(2).

20. Nelwan GB, Wangko S, Pasiak TF. Gambaran makroskopik dan mikroskopik otot skelet pada hewan coba postmortem. eBm. 2016;4(2).

21. Rajani T. A study on estimation of time since death after histological examination of kidney. Int J Res Med Sci. 2015;3(5): 1091-6 